\title{
Improved hydropower utilization design of the entire Wuding river in Yulin, Shaanxi
}

\author{
Tuo Liu*
}

Shaanxi Province Institute of Water Resources and Electric Power Investigation and Design, Xi'an, Shaanxi, 710001

\begin{abstract}
Below Cuijiawan, the main stream of Wuding River is basically a canyon section with exposed bedrock in the channel, intermittent plunging rapids, steep riverbed ratio and steep rock walls on both sides, which has favorable conditions for the construction of hydropower projects and is a key section for hydropower exploitation. Through research and analysis of the current water energy development and utilization, this paper combines the comprehensive improvement planning objectives and design ideas to propose a water energy utilization design that is consistent with the actual situation of Wuding River and reasonably budgeted, so that the abundant water energy resources of Wuding River can be fully utilized and the social, economic and ecological benefits can be unified.
\end{abstract}

Keyword: Wuding River; Water energy utilization; Generating capacity; Installed capacity.

\section{Introduction}

The Wuding River is a primary tributary of the Yellow River and the mother river of the Yulin people. It originates from the northern foot of Changchunliang, Baiyu Mountain in Yulin City, flows through Ordos City in Inner Mongolia, Yulin and Yan'an cities in Shaanxi Province, and joins the Yellow River at Hekou Village in Qingjian County. The Wuding River is $491.2 \mathrm{~km}$ long, with a basin area of $30,261 \mathrm{~km}^{2}$. The Wuding River in Yulin is $442.8 \mathrm{~km}$ long, The watershed area is $20,302 \mathrm{~km}^{2}{ }^{[1]}$.

Before the Qin and Han Dynasties, the Wuding River was known as the Sheyan River, and during the Northern and Southern Dynasties, it was known as the Xiashui and Shuofangshui. Since the Tang and Five Dynasties, the river has been called the Huanghudu River and the Wuding River because of its indefinite course, uncertain depth, indefinite volume, and indefinite clarity. Departing from the mountain stream area, it flows through the desert arid area all the way northward and passes through the southern edge of the Maowusu Sandy Land at the junction of Shaanxi and Inner Mongolia, turns eastward to Batuwan in Inner Mongolia, crosses the loess hills and ravines to the Yuhe Fort in Yulin and turns to flow southeast. Meandering southward, the river flows in the shape of a zigzag across the land of Yulin, like a kind mother with her warm arms open. The river nourishes $61 \%$ of the city's population, covers more than $80 \%$ of grain production regions, and contributes $42 \%$ of the city's total GDP.

\footnotetext{
*Corresponding author: 270689085@qq.com
} 
The Wuding River basin occupies a strategically important position as a gathering place for urban population, a centralized zone for industrial development, a backbone hub for transportation, a benchmark for ecological balance, a water supply carrying area, and a core cultural landscape area in Yulin City. With the rapid development of the city's economy and society, the water security of the Wuding River also presents a severe situation where old and new problems are intertwined. The water quantity is decreasing rapidly, water quality is deteriorating, flood control capacity is decreasing, soil erosion is serious, and shoreline management is not standardized, which seriously affects the life of the river, the ecology of the river basin, people's welfare and economic development. Therefore, the Wuding River Basin is in urgent need of comprehensive improvement.

\section{Development and utilization status}

The main stream of Wuding River in Yulin City has a length of $442.8 \mathrm{~km}$, a drop of $589 \mathrm{~m}$, and an average annual flow of $36.5 \mathrm{~m}^{3} / \mathrm{s}$. Theoretical hydro energy reserves in the basin are 209.0MW, including $163.8 \mathrm{MW}$ in the main stream, $43.3 \mathrm{MW}$ in installed capacity for technical exploitation, $43.30 \mathrm{MW}$ in installed capacity for economic exploitation, and 15.75MW in installed capacity for the exploited and under exploitation ${ }^{[3]}$.

Below Cuijiawan, the main stream of Wuding River is basically a canyon section, with exposed bedrock in the channel, intermittent plunging rapids, steeper riverbed drop of more than $170 \mathrm{~m}$, a narrow valley with a width of $80 \mathrm{~m} \sim 120 \mathrm{~m}$, and steep rock walls on both sides, which has favorable conditions for the construction of hydropower projects and is a key section for hydropower development.

There is a hydrological station at Baijiachuan in this section of the river, with a control basin area of $29,662 \mathrm{~km}^{2}$, and the information from this station was adopted in this design scheme. According to the hydrological data, the multi-year average runoff of Baijiachuan hydrological station is 862 million $\mathrm{m}^{3}$ with an average flow rate of $27.33 \mathrm{~m}^{3} / \mathrm{s}$. According to the analysis of the measured sediment data of Baijiachuan (Chuankou) hydrological station of Wuding River, the multi-year average sediment transport of suspended mass is 212 million $t$, and the annual average sediment transport of nudged mass is 42 million $t$. The multi-year average sediment transport of Baijiachuan hydrological station is 254 million $t$.

This section of the river is located in the composite part of the horseshoe-shaped betwixtoland of the zigzag Heilan Mountains and the northward slope of the northern Shaanxi in the Yikezhao League-Shaanxi Betwixtoland of the third neocathaysian subsidence zone. The bedrock is Paleozoic and Mesozoic sedimentary rocks, with a lot of Mesozoic rocks exposed, and a set of well cemented sandstones in the strata of dyas and triassic systems. The exposed strata in the area are Jurassic sandstone, and the attitude is nearly horizontal. Folds and faults are rare in this area. Since the Quaternary period, the crust in this area is mainly seismic uplift, with strong erosion and undercutting, and the development of gullies and valleys, forming the topography of loess hills and gullies. According to the Seismic Ground Motion Parameters Zonation Map of China (GB18306-2015), the basic intensity of the earthquake in this area is Grade VI.

Up to now, four hydropower stations have been built in the main stream of Wuding River from upstream to downstream in Yulin City: Wanggedu Reservoir Dam-toe Hydropower Station, Xiangshui Hydropower Station, Suide Hydropower Station and Dongfeng Hydropower Station. Except Wanggedu Reservoir Dam-toe Hydropower Station which is a reservoir hydropower station, the other three are diversion-type hydropower stations, all of which were built in the 1960s and 1970s and are still in normal operation. Wanggedu Reservoir Dam-toe Hydropower Station is located on the right bank of the dam, with a maximum diversion flow of $13.0 \mathrm{~m}^{3} / \mathrm{s}$ in power generation and a minimum diversion flow of $8.82 \mathrm{~m}^{3} / \mathrm{s}$. The hydropower station has a guaranteed output of $1,575 \mathrm{~kW}$, a total 
installed capacity of $3,750(3 \times 1,250) \mathrm{kW}$, and an average annual generating capacity of 19.4 million $\mathrm{kW} \cdot \mathrm{h}$. Dongfeng Hydropower Station has an installed capacity of $6,000 \mathrm{~kW}$, and an average annual generating capacity of 32 million $\mathrm{kW} \cdot \mathrm{h}$. It is the largest hydropower station in Yulin City. The main indexes of hydropower stations available in the main stream of Wuding River are shown in Table 1.

Table 1. Main indexes of hydropower stations available in the main stream of Wuding River in Yulin City ${ }^{[4]}$.

\begin{tabular}{|c|c|c|c|c|c|}
\hline Item & Unit & $\begin{array}{l}\text { Wanggedu } \\
\text { Reservoir } \\
\text { Dam-toe } \\
\text { Hydropower } \\
\text { Station }\end{array}$ & $\begin{array}{l}\text { Xiangshui } \\
\text { Hydropower } \\
\text { Station }\end{array}$ & $\begin{array}{c}\text { Suide } \\
\text { Hydropower } \\
\text { Station }\end{array}$ & $\begin{array}{l}\text { Dongfeng } \\
\text { Hydropower } \\
\text { Station }\end{array}$ \\
\hline Construction site & $\begin{array}{l}\text { County } \\
\text { (District) }\end{array}$ & Hengshan District & $\begin{array}{c}\text { Hengshan } \\
\text { District }\end{array}$ & Suide County & $\begin{array}{l}\text { Qingjian } \\
\text { County }\end{array}$ \\
\hline $\begin{array}{c}\text { Multi-year average } \\
\text { flow rate }\end{array}$ & $\mathrm{m}^{3} / \mathrm{s}$ & 10.75 & 20 & 47 & 48 \\
\hline $\begin{array}{c}\text { Development } \\
\text { method }\end{array}$ & & Dam-toe type & Diversion type & Diversion type & Diversion type \\
\hline $\begin{array}{c}\text { Normal water } \\
\text { storage level }\end{array}$ & $\mathrm{m}$ & 1046 & 970 & 771 & 618 \\
\hline $\begin{array}{c}\text { Regulating } \\
\text { performance }\end{array}$ & & Years & No & No & No \\
\hline $\begin{array}{l}\text { Available drop } \\
(\max / \mathrm{min})\end{array}$ & $\mathrm{m}$ & 8.1 & $31 / 30$ & $12.9 / 13.5$ & 29.8 \\
\hline Installed capacity & $\mathrm{kw}$ & 3750 & 3600 & 2400 & 6000 \\
\hline Guaranteed output & $\mathrm{kw}$ & 1575 & & & \\
\hline $\begin{array}{c}\text { Annual generating } \\
\text { capacity }\end{array}$ & $\begin{array}{l}10,000 \\
\mathrm{kw} \cdot \mathrm{h}\end{array}$ & 1940 & 1600 & 1320 & 3200 \\
\hline $\begin{array}{l}\text { Power generation } \\
\text { and diversion flow }\end{array}$ & $\mathrm{m}^{3} / \mathrm{s}$ & 13 & 15.0 & 26.2 & 24.0 \\
\hline Dam type & & $\begin{array}{l}\text { Homogeneous } \\
\text { earth dam }\end{array}$ & & Overflow dam & Overflow dam \\
\hline $\begin{array}{l}\text { Maximum dam } \\
\text { height }\end{array}$ & $\mathrm{m}$ & 44 & & 7.3 & 7 \\
\hline $\begin{array}{c}\text { Length of } \\
\text { diversion channel }\end{array}$ & $\mathrm{m}$ & 341.6 & & 475 & 119 \\
\hline
\end{tabular}

\section{Design ideas}

1) Adhere to the harmony of human and water, scientific development. Properly handle the relationship between small hydropower development and ecological protection of rivers, to achieve the greening of the whole process of small hydropower planning, construction, operation and management stages.

2) Adhere to land-specific conditions and promote by category. Taking full account of the actual situation in each place, the new small hydropower station should be prevented strictly from the source, without new debts. Small hydropower stations that have been built should urgently manage the ecological and environmental problems that exist, and repay old debts as much as possible.

3) Adhere to both incentives and constraints, with double-handed efforts. Formulate policies and measures to facilitate the construction of green small hydropower stations, while strengthening the strict control of the process, strict punishment for damage, and 
accountability.

4) Adhere to the government-led approach and multi-party engagement. The government should develop green standards, and improve regulations and policies. Hydropower station owners should fulfill the main responsibility of its implementation, and play the role as social organizations and allow for the supervision of the public.

In terms of hydropower resources, we should adhere to the principles of moderate development, comprehensive utilization, balanced development and protection, correctly handle the relationship between hydropower development and ecological protection, and adhere to the priority of ecology:

1] Do not plan hydropower stations in all the rivers in the nature reserves, scenic spots and areas designated by law and defined areas prohibited from development, as well as sensitive areas of important ecological environment for endangered, rare and endemic protected animals and plants.

2] Prioritize the development of hydropower stations attached to the comprehensive use of water conservancy hub projects and hydropower stations by changing the function of the original water conservancy project or by tapping the potential of such a project.

3] Adjust the development methods of rivers to promote the development of rivers for the originally planned power stations with large losses due to migration and inundation.

4] Prioritize the planning of the leading cascade hydropower station to improve the efficiency of water resources utilization and the overall effectiveness of the basin development. Fully demonstrate the relationships between the cascades of the rivers mainly developed by diversion-type hydropower station, in order to reduce the length of the off-stream.

5] Prioritize the planning of hydropower stations with tourism and ecological functions, and realize more social functions of hydropower stations, so as to drive the rapid development of regional economy and society.

6] Consider the hydropower development and ecological protection of the main streams and tributaries, upstream and downstream, and make the organic connection between the development and planning of the main streams and tributaries.

\section{Hydropower design}

In the northern Shaanxi region, we should focus on ecological environment management and protection, and develop hydropower according to local conditions by combining the construction of photovoltaic and wind power projects in northern Shaanxi so as to realize the complementarity of hydropower, photovoltaic and wind power. At the same time, the technical transformation of the built hydropower stations should be carried out to increase the effective output. Dam-toe hydropower stations should be built in conjunction with the comprehensive utilization of water resources, in order to serve the water consumption of energy and chemical bases and urban and rural residents, and to improve the utilization rate of hydropower resources.

According to the "Shaanxi Province Small Hydropower Development and Utilization Plan" (revised) completed in 2016, the cascade sequence for the eight planned hydropower stations in the main stream of the Wuding River in Yulin City are: Wanggedu Reservoir Dam-toe Hydropower Station (established), Xiangshui Hydropower Station (established), Suide Hydropower Station (established), Lijiawa Hydropower Station, Cuijiata Hydropower Station, Chuankou Hydropower Station, Wangsuli Hydropower Station and Dongfeng Hydropower Station (established). These hydropower stations have a total installed capacity of $42.7 \mathrm{MW}$, with an annual generating capacity of 183.49 million $\mathrm{kW} \cdot \mathrm{h}$. As the planned Wangsuli Hydropower Station is located in the backwater area of Guxian Reservoir, the former level-4 stations of Lijiawa and Wangsuli is now adjusted to level-3 
stations of Lijiawa, Dongfanghong and Xinchuankou. Accordingly, the design includes three new hydropower stations with an additional installed capacity of $31.05 \mathrm{MW}$ and an annual generating capacity of 119.63 million $\mathrm{kW} \cdot \mathrm{h}$. The main indicators of the proposed stations are shown in Table 2.

Table 2. Main indicators of the planned hydropower stations in the main stream of the Wuding River in Yulin City ${ }^{[2]}$.

\begin{tabular}{|c|c|c|c|c|c|c|c|}
\hline No. & Station name & $\begin{array}{c}\text { County } \\
\text { (district) }\end{array}$ & $\begin{array}{c}\text { Township } \\
\text { (town) }\end{array}$ & $\begin{array}{c}\text { Development } \\
\text { method }\end{array}$ & $\begin{array}{c}\text { Maximum } \\
\text { water head } \\
(\mathrm{m})\end{array}$ & $\begin{array}{c}\text { Installed } \\
\text { capacity } \\
\text { (MW) }\end{array}$ & $\begin{array}{c}\text { Annual } \\
\text { generating } \\
\text { capacity } \\
(10,000 \\
\mathrm{kW} \cdot \mathrm{h})\end{array}$ \\
\hline 1 & Lijiawa & $\begin{array}{c}\text { Qingjian } \\
\text { County }\end{array}$ & $\begin{array}{c}\text { Dianzegou } \\
\text { Township }\end{array}$ & Diversion type & 31 & 7.65 & 3109 \\
\hline 2 & Dongfanghong & $\begin{array}{c}\text { Qingjian } \\
\text { County }\end{array}$ & $\begin{array}{c}\text { Gaojiecun } \\
\text { Town }\end{array}$ & Diversion type & 43.1 & 15 & 5458 \\
\hline 3 & Xinchuankou & $\begin{array}{c}\text { Qingjian } \\
\text { County }\end{array}$ & $\begin{array}{c}\text { Gaojiecun } \\
\text { Town }\end{array}$ & Diversion type & 33 & 8.4 & 3396 \\
\hline Total & & & & & & 31.05 & 11963 \\
\hline
\end{tabular}

\section{Conclusions}

1) Developing hydropower resources with the principle of prioritizing ecology and building green small hydropower stations as the basic requirement.

2) Taking hydropower for people's livelihood, safe hydropower, green hydropower, and harmonious hydropower as the ultimate goal of hydropower resources development and utilization. We should initially form a new pattern of hydropower resources development, utilization and construction with the construction of water ecological civilization as the main line. Moreover, we should build a water security system that is compatible with the well-off society and promote the sustainable economic and social development of Yulin City.

3) Through rational planning, scientific planning and orderly development of hydropower resources, we should minimize the negative impact of hydropower projects on the ecological environment and keep the structure and function of river ecosystems in a sound state, so as to realize the unity of social, economic and ecological benefits.

\section{References}

1. The Bureau of Water Affairs of Yulin City, Shaanxi Province Institute of Water Resources and Electric Power Investigation and Design. Comprehensive Improvement Plan for the Entire Wuding River in Yulin City, 2017.

2. Shaanxi Provincial Water Resources Department. Planning for the Development and Utilization of Small Hydropower Projects in Shaanxi Province, 2016.

3. Yellow River Conservancy Commission of the Ministry of Water Resources. Comprehensive Plan for the Wuding River Basin, 2014.

4. Shaanxi Provincial Water Resources Department.Report on Integrated Planning of Wuding River Basin in Shaan xi Province,2012. 